\title{
The Welfare Implications of the European Trucks Cartel
}

This paper presents a pragmatic approach to calculating the total economic loss induced by a cartel, focusing on the European trucks cartel (1997-2011). This comprehensible and transparent approach builds on the theory of monopoly pricing and uses the publicly available data of the infringing companies. Overall, a net welfare loss of up to 15.5 billion euro and an overcharge to the amount of up to $7.6 \%$ are estimated. This loss to society cannot be offset by fines or private damage claims and should raise awareness for antitrust policy. The findings presented are relevant for both practitioners and policymakers.

With the enforcement of Directive 2014/104/EU (2014), the facilitation of private damage claims against cartels has spread throughout the European Economic Area (EEA). Cartel overcharge, the basis for private damage claims, is highly topical. ${ }^{1}$ In fact, the number of cartel damage claims in European courts rose from a mere 18 in January 2009 to over 70 in October 2016 (Laborde, 2017, 36). From a legal perspective, private damage claims are second only to public damage claims (fines) - the second pillar for calling competition law offenders to account. While fines primarily aim to deter undertakings from future violations of antitrust law, private damage claims enforce the redistribution of cartel profits to the customer. Cartel profit is

(C) The Author(s) 2020. Open Access: This article is distributed under the terms of the Creative Commons Attribution 4.0 International License (https://creativecommons.org/licenses/by/4.0/).

Open Access funding provided by ZBW - Leibniz Information Centre for Economics.

1 The EU defines cartel overcharge as the difference between the price actually paid and the price that would otherwise have prevailed in the absence of an infringement of competition law (Directive 2014/104/ EU, 2014, 11).

Christian Beyer, OWL University of Applied Sciences and Arts, Lemgo, Germany.

Elke Kottmann, OWL University of Applied Sciences and Arts, Lemgo, Germany.

Korbinian von Blanckenburg, OWL University of Applied Sciences and Arts, Lemgo, Germany. the excess profit (cartel overcharge multiplied by the total quantity sold) that the cartel was able to reap during the period of infringement. In short, public claims aim at deterrence, while private claims aim at compensation (corrective justice).

However, the economic loss induced by a cartel is more than just the redistribution of rent from consumers to producers. ${ }^{2}$ Economists have long agreed that cartels induce an additional, allocative, deadweight loss to society: a loss to the consumer that is not balanced by any gain reaped by the monopolist. The allocative damage refers to the misallocation of resources and originates from potential transactions. This is the overall net loss of the cartel. The magnitude of the deadweight loss is particularly relevant for governments (re)considering their antitrust policies and for societal perceptions of cartels and public antitrust enforcement. We provide a pragmatic approach to calculating the total loss caused by a cartel, focusing on the prominent case of the trucks cartel. The results enable us, firstly, to adopt a societal perspective, i.e. to compare total damage (deadweight loss and overcharge) to total fines (public and private), and secondly, to calculate cartel overcharge based on profit data. The latter is of particular importance in cases of list price collusion such as the trucks cartel.

2 From the viewpoint of the society as a whole, this redistribution is not a real loss, since wealth is merely shifted between different agents and not lost. Nevertheless, from a normative point of view, it is a distributive loss. 
Figure 1

The structure of the European trucks cartel

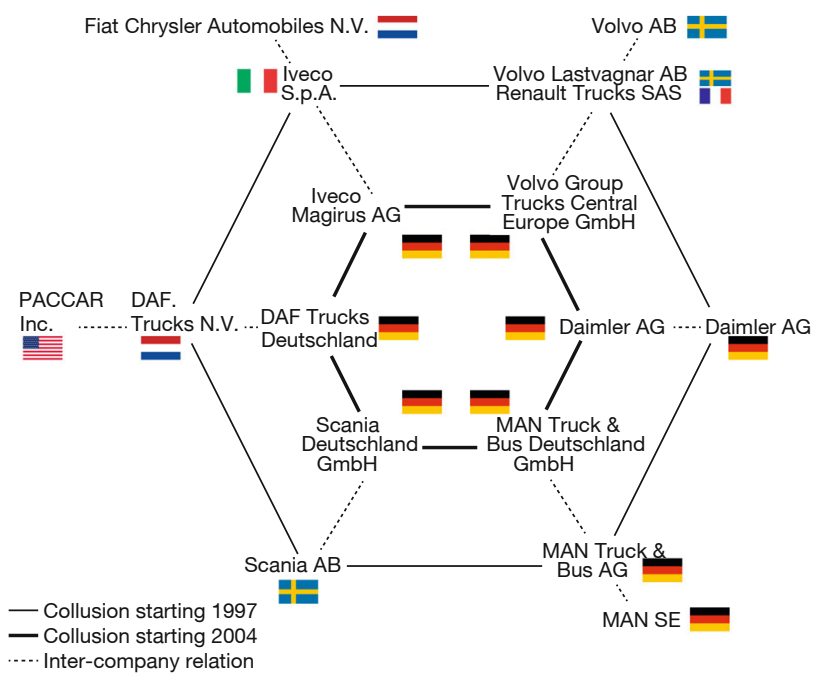

Source: Authors' own illustration.

The European trucks cartel: Price collusion for 14 years

On 17 January 1997, a meeting of senior-level managers of the six European truck producers, namely DAF, Daimler, Iveco, MAN, Scania and Volvo marked the starting point of the trucks cartel. In that meeting, the defendants exchanged information on gross list prices for medium and heavy trucks in the EEA. ${ }^{3}$ This practice continued, in varying degrees, for 14 years, until the cartel was finally dissolved after MAN had applied for immunity under the European Commission's (henceforth the Commission) leniency programme. The price collusion included the coordination of gross list prices for medium and heavy trucks and the coordination of the pricing and timing of technologies, so as to comply with the impending emission standards Euro 3-6. Further attempts to limit competition by increasing market transparency included the exchange of truck configurators (sales software to customise firmspecific truck offers) and the exchange of information on delivery times. In total, 17 legal entities were involved in the trucks cartel. They are charged with different degrees of collusion and varying periods of infringement (see Figure 1).
Table 1

Summary of fines imposed on the trucks cartel

\begin{tabular}{lccr} 
& $\begin{array}{c}\text { Reduction under } \\
\text { the Leniency Notice } \\
(\%)\end{array}$ & $\begin{array}{c}\text { Reduction } \\
\text { under the } \\
\text { Settlement } \\
\text { Notice (\%) }\end{array}$ & $\begin{array}{c}\text { Fine } \\
\text { (thousand euro) }\end{array}$ \\
\hline MAN & 100 & 10 & 0 \\
\hline Volvo/Renault & 40 & 10 & 670,448 \\
\hline Daimler & 30 & 10 & $1,008,766$ \\
\hline Iveco & 10 & 10 & 494,606 \\
\hline DAF & 0 & 10 & 752,679 \\
\hline Scania & 0 & 0 & 880,523 \\
\hline Total & & & $3,807,022$ \\
\hline
\end{tabular}

Source: Commission Decision C(2016) 4673, 19.7.2016, CASE AT.39824 Trucks; European Commission Press Release IP/17/3502 and European Commission Statement/17/3509.

\section{Layers of collusion}

Three layers of collusion can be identified: the parent level, comprising the parent companies of the respective group; the headquarter level, comprising the national headquarters of the group's truck division; and the German level, comprising the groups' German subsidiaries. The parent companies have been involved in the cartel only in an indirect manner via their subsidiaries. ${ }^{4}$ The headquarter level held collusive talks beginning on 17 January 1997. These where gradually replaced by agreements at the German level until 2004. That is, at least since 2004, the cartel used German subsidiaries as its vehicle of operation. After the Commission opened the inspections, Daimler, Iveco and Volvo/Renault applied for immunity from fines in accordance with Point 14 of the Leniency Notice (Commission Notice C298, 2006, 17). Scania did not settle with the Commission and was fined 880 million euro in September 2017. Table 1 lists the total fines imposed on the defendants.

\section{Dominance on the European truck market}

The sales process in the truck market is based on individual transactions. Gross list prices (GLP) for each truck model are the starting point of truck pricing. Reductions of the GLPs are then usually negotiated with individual customers, either by independent dealers or by the producers' sales personnel. Truck offers are thus specific to customer requirements of the vehicle and to the individual

4 The only exception in this regard is Daimler, for which, due to the legal structure of the group, Daimler AG is responsible for infringements in all three layers of the cartel. 
net price negotiations (rebates). Trucks are manufactured in a modular production system such that the degree of vehicle customisation is limited and customers are able to compare modules from different producers. Third-degree price discrimination (individual prices) is an obstacle to price collusion, which is why the trucks cartel was able to coordinate prices at the GLP level only. In the relevant product market, segments II and III of the truck market in the EEA from 1997 to 2011, the six defendants were the only suppliers. Within this group, Daimler is the clear market leader, followed by Volvo and MAN. ${ }^{5}$ Truck registrations in Europe averaged 340,000 units during the cartel phase, out of which 240,000 units have been heavy trucks above 16 tonnes (segment III). ${ }^{6}$

\section{Impact on the global truck industry}

At the end of the cartel phase, the European truck producers directly controlled more than $20 \%$ of the global production of medium and heavy trucks. Thus, besides their dominance in Europe, the European truck producers' competitive conduct is of considerable international relevance. The global truck industry can be divided into four regions, namely Europe, North America, Japan (together referred to as the triad) and China. Regions outside these four major markets have only limited influence on the structure of competition in the global truck industry (Nilsson and Dernroth, 1995). Even within the triad, the Japanese market differs significantly from those of Europe and North America. Japanese legislation concerning the size and capacity of trucks is different from standards in Europe and North America, such that Japanese producers have historically refrained from building and exporting (heavy) trucks aligned with the standards in other markets. In both North America and China, the European truck producers have acquired substantial production capacities, or formed strategic alliances with foreign producers, with whom they jointly control more than $50 \%$ of global production.

The structure of the global truck industry has two main implications for the political and economic analysis of the trucks cartel. First, anticompetitive conduct in Europe might well spill over to other regions, since the decisive companies are more or less the same. Second, the European producers have the market power to prevent for-

5 Our data for the year 2016 imply the following market shares: Daimler (26.1\%), Volvo (23.8\%), MAN (19.4\%), Scania (11.6\%), DAF (10.6\%), Iveco (8.5\%).

6 Segment II is, however, slightly smaller than the remaining 100,000 units, since the threshold for counting medium trucks (segment II) differs registration figures that are based on a threshold of 3.5 tonnes, the Commission's market segmentation is based on a threshold of 6 tonnes. eign competition in their home market. In addition, truck production abroad generally requires substantial foreign direct investment, and imports/exports of trucks induce considerable shipment and homologation costs. These represent effective entrance barriers to producers outside Europe (Popper et al., 2004). Foreign competition in the EEA is thus unlikely.

\section{Calculating the deadweight loss}

The economic damage linked to the existence of a cartel is usually expressed in terms of inefficiencies. The economic literature identifies three types of inefficiency: allocative, productive and dynamic. We focus on allocative inefficiency, i.e. the misallocation of resources resulting from distorted prices. The concept of allocative inefficiency extends to work on the theory of monopoly and welfare, starting with Cournot (1838) and Dupuit (1844), complemented by Pigou (1910), Lerner (1934) and Harberger (1954). The latter himself estimated the deadweight loss to be less than $0.1 \%$ of gross national product in the United States; subsequent empirical studies on monopolies based on Harberger's model largely confirm this result. The (at the time of publication) surprising result that the deadweight loss of a monopoly is almost negligible still prevails among economists. Even though Harberger's methodology has triggered criticism regarding its assumptions, it remains the workhorse model in partial equilibrium analysis of monopolies.?

Due to their collective action, cartels enable monopolistic pricing. Their welfare implications are thus analysed similarly to those of a monopoly. Since all six European truck producers have participated actively in the trucks cartel, the entire European truck production in its respective segments has been under the supervision of the cartel between 1997 and 2011. This allows us to treat the six truck manufacturers as one monopolist and apply the methodology used to calculate the welfare loss of a monopoly. To the best of our knowledge, this is the first time that deadweight losses à la Harberger are calculated for a real-world cartel case. The methodology we apply builds upon the very simple and familiar model shown in Figure 2.

\section{Methodology of the model}

The underlying assumptions of this textbook model include a linear demand curve and constant average (mar-

7 The assumptions of the model are strong but conventional. See the general critique of Stigler (1956) and Bergson (1973) on unitary price elasticity. If the price elasticity of demand is $>1$ in reality, our results should be interpreted as a lower bound of the damage. 
Figure 2

\section{Welfare effects of a monopoly}

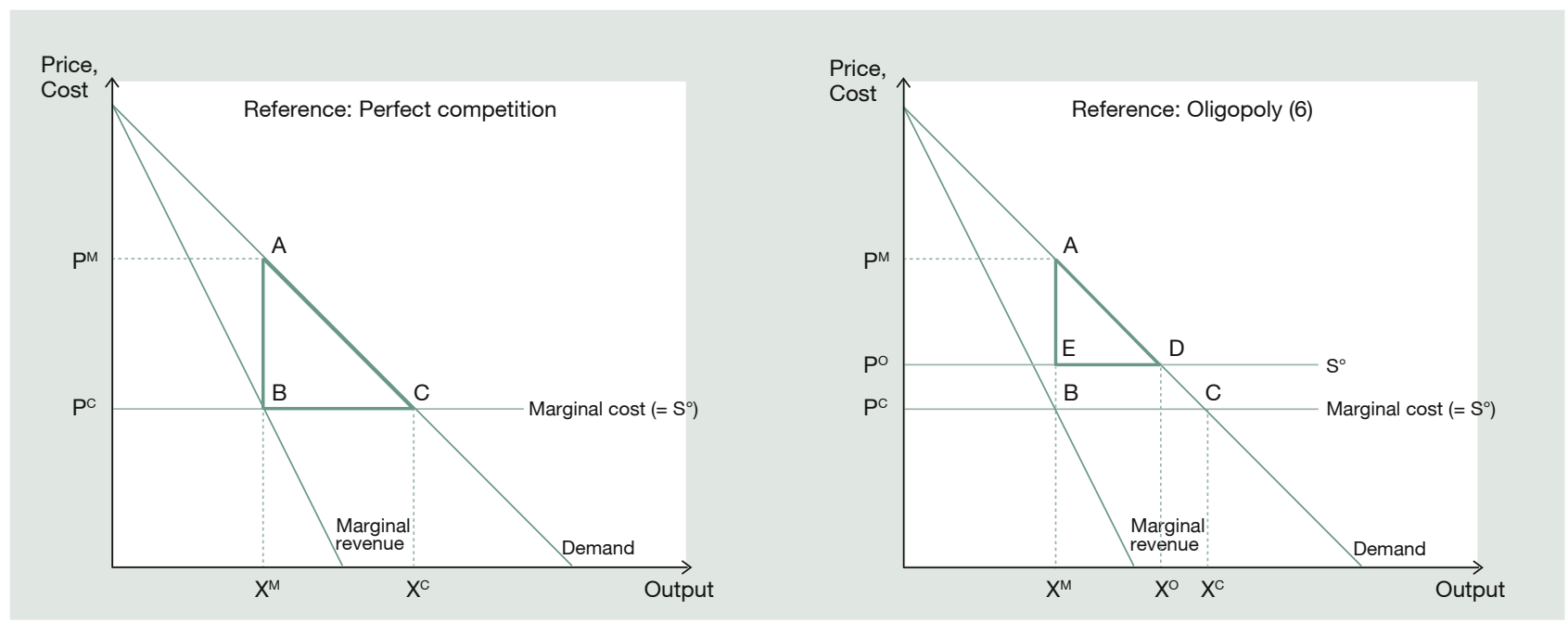

Source: Authors' own elaboration.

ginal) cost. The cartel is able to establish a market price $\mathrm{P}^{\mathrm{M}}$ above the competitive price and thus realises cartelinduced profits amounting to the rectangle $\mathrm{P}^{\mathrm{M}} \mathrm{ABP} \mathrm{C}^{\mathrm{C}}$ (cartel overcharge multiplied by total quantity). In addition, triangle $A B C$ captures the deadweight welfare loss, referred to as allocative loss $(A L)$. We estimate this social damage, following the approach of Shinjo and Doi (1989). The area of triangle $\mathrm{ABC}$, henceforth $\triangle \mathrm{AL}$, is represented by

$$
A L=1 / 2 *(A B) *(B C)=1 / 2 *\left(P^{M}-P^{C}\right) *\left(X^{C}-X^{M}\right)
$$

Since $\mathrm{PC}^{\mathrm{C}}$ and $\mathrm{X}^{\mathrm{C}}$ are counterfactuals by nature and thus unobservable, we reformulate $\triangle \mathrm{AL}$ as follows: $\triangle \mathrm{AL}=\Delta \mathrm{P}$ * $\Delta \mathrm{X}=1 / 2$ et $^{2} \mathrm{~S}$, where $\mathrm{t}$ is the profit margin $\left(\mathrm{t}=\Delta \mathrm{P} / \mathrm{P}^{\mathrm{M}}\right), \mathrm{S}$ is sales and $e=\left(\Delta X / X^{M}\right) *(P M / \Delta P)$ is the price elasticity of demand. ${ }^{8}$

The results of the model crucially depend on the value of e. We approach this issue by calculating the model with two distinct values for e, which we regard as the upper and lower limit. First, as Shinjo and Doi (1989), we assume an elasticity of one, referring to studies showing that industry specific elasticities tend to cluster around 1.0. However, given their (and our) model specification, an elasticity of one implies that the marginal costs of truck production are zero. As the Cournot optimum, by definition, falls into the more elastic part of the demand function, we regard our results based on an elasticity of one as the lower bound of potential allocative loss. If

8 Substituting $\mathrm{t}=\Delta \mathrm{P} / \mathrm{P}^{\mathrm{M}}$ and $\Delta \mathrm{X}=\mathrm{eX}^{\mathrm{M}}$ t into $\Delta \mathrm{AL}$ yields $\Delta \mathrm{AL}=\mathrm{P}^{\mathrm{M}} \mathrm{eX}^{\mathrm{M}} \mathrm{t}^{2}$, from which follows $\Delta A L=1 / 2$ et $^{2} S$. we instead assume that the cartel members behave as strict profit maximisers, the elasticity would be $1 / \mathrm{t}$. This is the case of perfect collusion and the results under this condition represent the upper bound of potential damage. In both approaches, we do not need to calculate the counterfactual quantity $\mathrm{X}^{\mathrm{C}}$ and have thus rewritten $\triangle \mathrm{AL}$ in terms of observable variables.

The remaining variables are identified as follows. $S$, the current sales figure, is observable in the annual reports of the cartel members. The cartel profit margin $t$, defined as the rate of cartel profits $\left(\Pi^{\mathrm{M}}\right)$ on sales $(\mathrm{S})$, where the latter is observed as before and $\Pi^{\mathrm{M}}$ is calculated by subtracting a counterfactual, competitive, profit from observed profits in the annual reports $\left(\Pi^{\circ}\right)$. Counterfactual profits are approximated by $r * A$, with $r$ being the competitive profit rate and $A$ being total assets, and thus $t=\left(\Pi^{\circ}-r A\right) / S$.

\section{The dataset: Availability and difficulties}

The data at hand provide us the variable $S$ on a disaggregated level; $t$ is calculated with data at the business unit level. The time series for the competitive profit rate $r$ originates from the Bank for the Accounts of Companies Harmonized (BACH) database, maintained by the Bank of France. It represents the ratio of net operating profit on total assets for large companies in the automotive industry of the participating European countries. We collected the data on the truck market from the annual reports of the affected companies. Table 2 gives a detailed overview about the variables used. We collected data for the entire duration of the infringement (1997-2011). However, these 
Table 2

Summary statistics of main variables in the dataset in billions of euros

\begin{tabular}{lrrrrr} 
& $\begin{array}{c}\text { Sales } \\
(\text { mean })\end{array}$ & $\begin{array}{c}\text { Sales } \\
(\mathrm{sd})\end{array}$ & $\begin{array}{c}\text { EBIT } \\
(\text { mean })\end{array}$ & $\begin{array}{c}\text { EBIT } \\
(\mathrm{sd})\end{array}$ & $\begin{array}{r}\text { Total assets } \\
(\text { mean })\end{array}$ \\
\hline Total industry & 31.56 & 8.22 & 4.03 & 3.04 & 59.60 \\
\hline DAF & 3.82 & 2.31 & 0.96 & 0.70 & 6.06 \\
\hline Daimler & 8.70 & 2.25 & 0.98 & 0.94 & 26.90 \\
\hline MAN & 5.94 & 1.66 & 0.40 & 0.32 & 6.03 \\
\hline Iveco & 2.86 & 0.46 & 0.34 & 0.24 & 10.50 \\
\hline Scania & 2.61 & 0.58 & 0.70 & 0.39 & 5.51 \\
\hline Volvo & 8.16 & 1.50 & 0.66 & 0.77 & 4.69 \\
\hline
\end{tabular}

Source: Authors' own calculation.

data are not directly available in an ideal fashion for economic analysis, i.e. we do not observe perfectly disaggregated data, neither at the product, nor at the regional level.
Some practical difficulties and specifics associated with our dataset prevail. First, participants in the trucks cartel are multiproduct firms. Data representation at the segment or business unit level is state of the art in the latest annual reports, but not for the entire period under consideration. That is, for some years, there is data at a higher level of aggregation only. This can introduce a productmix bias and a geographical bias, since some levels of aggregation cover operations in a larger region than the cartel's area of influence. Moreover, firms have adjusted their group structure from time to time. The most prominent example during the infringement period is the merger of Daimler-Benz and Chrysler in 1998 and their dissolution in 2007. Beyond the structural challenges, firms have an incentive not to report disaggregated data (due to competitive intelligence considerations) and to disguise the reported data wherever possible. We provide firm-level details on these caveats in Table 3. However, the data available are, to a large extent, satisfactory with regard to our methodological approach and are the only data avail-

Table 3

Firm-level details on data availability

\begin{tabular}{|c|c|c|c|c|}
\hline Defendant & Company reporting & Unit of account & Calculation of $t$ & Calculation of $\mathrm{S}$ \\
\hline \multirow[t]{2}{*}{ Daimler } & Daimler AG (2006-2011) & $\begin{array}{l}\text { Daimler Trucks incl. medium and } \\
\text { heavy trucks, specialty vehicles (global) }\end{array}$ & $\begin{array}{l}\text { BU-level: Net assets, } \\
\text { EBIT and sales }\end{array}$ & $\begin{array}{l}\text { European truck sales are reported } \\
\text { directly (disaggregated reporting) }\end{array}$ \\
\hline & $\begin{array}{l}\text { DaimlerChrysler AG } \\
(1997-2005)\end{array}$ & $\begin{array}{l}\text { Nutzfahrzeuge incl. trucks, } \\
\text { buses and vans (global) }\end{array}$ & $\begin{array}{l}\text { BU-level: Net assets, } \\
\text { EBIT and sales }\end{array}$ & $\begin{array}{l}\text { Sales in Europe, adjusted for vans and } \\
\text { buses, using data on the composition of } \\
\text { sales quantities. }\end{array}$ \\
\hline DAF & Paccar Inc. (1997-2011) & $\begin{array}{l}\text { Trucks incl. trucks } \\
\text { of all segments (global) }\end{array}$ & $\begin{array}{l}\text { BU-level: Total assets, } \\
\text { EBIT and sales }\end{array}$ & $\begin{array}{l}\text { European truck sales are reported } \\
\text { directly (disaggregated reporting) }\end{array}$ \\
\hline \multirow[t]{2}{*}{ Iveco } & Fiat Industrial S.p.A. (2011) & $\begin{array}{l}\text { Commercial Vehicles (Iveco) } \\
\text { incl. trucks of all segments, buses } \\
\text { and specialty vehicles (mostly Europe) }\end{array}$ & $\begin{array}{l}\text { BU-level: Operating as- } \\
\text { sets }^{\star \star} \text {, } \\
\text { EBIT and sales }\end{array}$ & $\begin{array}{l}\text { Truck sales in Europe, debugged from } \\
\text { operations outside Europe }(\approx 30 \%) \text { and } \\
\text { vehicles type other than medium and } \\
\text { heavy trucks }(\approx 50 \%)\end{array}$ \\
\hline & Fiat Group (1997-2010) & $\begin{array}{l}\text { Commercial Vehicles (Iveco) } \\
\text { incl. trucks of all segments, buses } \\
\text { and specialty vehicles (mostly Europe) }\end{array}$ & $\begin{array}{l}\text { BU-level: Operating } \\
\text { assets*, } \\
\text { EBIT and sales }\end{array}$ & $\begin{array}{l}\text { Truck sales in Europe, debugged from } \\
\text { operations outside Europe }(\approx 30 \%) \text { and } \\
\text { vehicles type other than medium and } \\
\text { heavy trucks }(\approx 50 \%)\end{array}$ \\
\hline \multirow[t]{2}{*}{ MAN } & MAN SE (2009-2011) & $\begin{array}{l}\text { MAN Truck \& Bus incl. medium } \\
\text { and heavy trucks, buses } \\
\text { (mostly Europe) }\end{array}$ & $\begin{array}{l}\text { BU-level: Total assets, } \\
\text { EBIT and sales }\end{array}$ & $\begin{array}{l}\text { European truck sales are reported } \\
\text { directly (disaggregated reporting); } \\
\text { data for } 1997-2000 \text { estimated }\end{array}$ \\
\hline & MAN AG (1997-2008) & $\begin{array}{l}\text { MAN Nutzfahrzeuge incl. medium } \\
\text { and heavy trucks, buses } \\
\text { (mostly Europe) }\end{array}$ & $\begin{array}{l}\text { BU-level: Total assets, } \\
\text { EBIT and sales }\end{array}$ & $\begin{array}{l}\text { European truck sales are reported } \\
\text { directly (disaggregated reporting); } \\
\text { data for } 1997-2000 \text { estimated }\end{array}$ \\
\hline Scania & Scania AB (1997-2011) & $\begin{array}{l}\text { Vehicles and Services incl. heavy } \\
\text { trucks, buses and services (global) }\end{array}$ & $\begin{array}{l}\text { BU-level: Total assets }{ }^{\star *} \\
\text { EBIT and sales }\end{array}$ & $\begin{array}{l}\text { European truck sales are calculated by } \\
\text { adjusting the reported global truck } \\
\text { sales for the share of units sold in } \\
\text { Europe }\end{array}$ \\
\hline Volvo & AB Volvo $(1997-2011)^{\star \star *}$ & $\begin{array}{l}\text { Volvo Trucks incl. trucks } \\
\text { of all segments and buses (global) }\end{array}$ & $\begin{array}{l}\text { BU-level: Total assets }{ }^{\star \star \star *} \text {, } \\
\text { EBIT and sales }\end{array}$ & $\begin{array}{l}\text { European truck sales are reported } \\
\text { directly (disaggregated reporting) }\end{array}$ \\
\hline
\end{tabular}

Note: BU-Level stands for business unit level.

* Data prior to 2004 had to be calculated using group-level data. ** Data for the years 1997-2000 are missing. We inserted the value for 2001 instead. ${ }^{* * *}$ From 2001 onwards: incl. Renault V.I.; older data have been adjusted so as to implicitly include RVI. **** Total assets of Volvo Trucks are estimated using the reported total assets of Volvo Lastvagnar AB and Renault Trucks SAS. Since data prior to 2007 are missing, we calculated the missing values based on the aforementioned, combined with group-level data.

Source: Authors' own elaboration. 
Table 4

Model results

\begin{tabular}{lrr} 
Scenario & $e=1$ & $e=1 / \mathrm{t}$ \\
\hline$\Delta$ AL Deadweight welfare loss (million euro) & 658.32 & $15,484.69$ \\
\hline$\Delta$ AL as \% of GDP (2011) & 0.01 & 0.33 \\
\hline Distributive loss (million euro) & $1,843.51$ & $43,362.35$ \\
\hline Overcharge (distributive loss per vehicle in euro) & 358.60 & $8,404.67$ \\
\hline
\end{tabular}

Source: Authors' own calculations.

able to the public at the end. We believe that under the guideline of Article 17 of the damages directive (pragmatism), the published accounting data provide a promising basis for cartel damage calculation.

\section{Determing a bandwith of the cartel damage}

The two distinct scenarios with regard to the price elasticity of demand enable us to provide a bandwidth of the damage. We estimate the deadweight welfare loss attributable to the trucks cartel at approximately $0.7-15.5$ billion euro. If the counterfactual market is perfectly competitive, $\triangle \mathrm{AL}$ comprises $50 \%$ of cartel-induced profits. ${ }^{9}$ By contrast, in the absence of a cartel, the truck market can be best characterised as a Cournot-type oligopoly with six firms. In this scenario, it can be shown that $\Delta \mathrm{AL}$ comprises $35.7 \%$ of cartel-induced profits (i.e. of rectangle $\mathrm{P}^{\mathrm{M}} \mathrm{AEP} \mathrm{O}^{\circ}$; right side of Figure 2). Considering this, the resulting distributive loss is between 1.8 and 43.4 billion euro. The total number of registered medium and heavy trucks during the cartel phase is 4.8 million, so that the distributive loss is between 360 and 8,400 euro per vehicle. This is an average overcharge of $0.3-7.6 \%$. Table 4 sums up the results.

Other types of damage caused by cartels

However, the welfare-analytical treatment of cartels as monopolies relies on the assumptions mentioned above and is, by definition, a static model. In that sense, it disregards two other types of damage. First, the cost of maintaining the cartel and coordinating its organisation adds to the deadweight loss. These costs represent wasted resources that would otherwise have been used efficiently. In the trucks cartel, for example resources were shifted to the collection, aggregation and communication of planned list-price increases. These resources could

9 Because, with linear demand and symmetric, constant marginal cost, marginal revenue has the same intercept, but twice the slope of the demand curve. have been used efficiently. Leibenstein introduced this kind of deviation from optimal behaviour and labeled it Xinefficiency (1966). Empirical evidence confirms a robust impact of competition on productivity (Schiffbauer and Ospina, 2010; Okada, 2005).

Second, the dynamic efficiency of the cartelised industry is affected. Dynamic inefficiencies are deviations from the optimal path of future innovations, caused by the elimination of competitive pressure. The dynamic damage is difficult to measure. Moreover, the relation between competition and innovation is vague. Theoretical arguments vary from clearly negative relations (profitability-driven) to clearly positive ones (incentive-driven). In recent empirical work, an inverted- $U$ relationship between competition and innovation prevails (Aghion et al., 2005; Peneder, 2012; Lambertini et al., 2017). That is, comparing the oligopoly to a quasi-monopoly (cartel) there is a clear positive relationship between competition and innovation.

These dynamic effects of delayed technological advancement are not included in our results. In our case, the reduced incentives for the cartel members to innovate have been accompanied by explicit collusion on the pricing of future innovations. To contextualise our results, we use two points of reference, namely the overcharge observed in past cartel cases and the welfare loss calculated for other monopolised markets. Compared to the welfare losses estimated by Harberger ( $0.1 \%$ of GNP), the loss caused by the trucks cartel fits the picture: $0.01-0.33 \%$. Monopolistic pricing behaviour, whether conducted by one (monopoly) or several (cartel) companies, induces similar dead weight losses to society. The magnitude of overcharges in cartel cases has been examined in a number of meta-studies. The hypothetical overcharge for EUwide cartels is commonly assumed to be $20 \%$ (Renda et al., 2006, 99). ${ }^{10}$ This benchmark is, however, a comparison to the competitive price. Instead, our point of reference is the equilibrium price in a six-firm oligopoly. Theoretically, the overcharge in this setting should be smaller. Our calculations suggest an overcharge of $0.3-7.6 \%$. This is the cartel overcharge on individual net prices payed by truck buyers. Collusion had, however, initially taken place on the level of gross list prices, where the agreed price increase might have been higher.

In essence, the overcharge that the truck producers were able to reap during the infringement was half that of the average cartel cases - at most. This might be due to the pricing scheme (gross and net prices) and the already elevated market prices for trucks because of the oligopolistic

10 In addition, the authors provide a survey of empirical studies on cartel overcharges. 
market structure. Potentially, the truck producers focused more on coordination and facilitating transparency as to (partially) enjoy the quiet life of the monopolist (Hicks 1935, 8). The exchange of truck configurators, delivery-time data and the exchange (rather than mutual elevation) of gross list prices provide circumstantial evidence for this.

\section{Public and private damage claims to deter cartel formation}

Recalling that overcharges, depending on the price elasticity, varied between 1.8 and 43.4 billion euro and fines as imposed by the Commission were 3.8 billion euro, it becomes clear that potential gains outweigh potential losses. The deterrence effect in this scenario is limited.

Since 2014, private damage claims can be enforced as well. Ideally, these private damage claims cover the entire overcharge, such that public fines represent an additional net loss to the defendants. Private damage claims can thus help to deter cartel formation. Both fines and private damage claims are needed to ensure that the net present value of cartel participation turns out to be negative. ${ }^{11}$

\section{Assessing the deadweight welfare loss of the trucks cartel}

To our knowledge, this study provides the first estimate of a deadweight welfare loss for a modern cartel case. The main outcomes can be summarised as follows:

- We estimate 0.7-15.5 billion euro of deadweight welfare loss;

- We estimate 1.8-43.4 billion euro cartel overcharges in total;

- That is, we find a $0.3-7.6 \%$ mark-up on the reference price.

The deadweight welfare loss is similar to that in other scenarios of monopolistic market power. The cartel overcharge is slightly lower than the average, albeit still substantial. Our simple approach has very modest data requirements. It is therefore suitable for cartel cases, for which the but-for price is difficult to calculate due to opaque pricing processes, the structure of the market or simply data availability. One caveat is, however, that it can be used to analyse markets with an entirely cartelised supply side, but not in cases of partial cartels.

11 It should, however, be acknowledged that private damage claims interact with other policy tools, such as the leniency programme, which might become less effective (Beschorner and Hüschelrath, 2010).
The demonstrated case of the trucks cartel yields two practical implications: first, we provide a benchmark for the overcharge per truck; and second, we show that the deadweight welfare loss is substantial. This loss to society cannot be offset by fines or private damage claims and should raise awareness for antitrust policy.

\section{References}

Aghion, P., N. Bloom, R. Blundell, R. Griffith and P. Howitt (2005), Competition and Innovation: An Inverted-U Relationship, The Quarterly Journal of Economics, 120(2), 701-728,

Bergson, A. (1973), On Monopoly Welfare Losses, The American Economic Review, 65(5), 853-870.

Beschorner, P. and K. Hüschelrath (2010), Ökonomische Aspekte der privaten Durchsetzung des Kartellrechts, in W. Möschel and F. Bien (eds.), Kartellrechtsdurchsetzung durch private Schadenersatzklagen?, Nomos, 9-24.

Commission Notice on Immunity from fines and reduction of fines in cartel cases (2006), Official Journal of the European Union, C298, 17-22.

Cournot, A. A. (1838), Researches into the Mathematical Principles of the Theory of Wealth, trans. N. T. Bacon, Macmillan, 1927.

Dupuit, J. (1844), On the measurement of the utility of public works, trans. R. H. Barback (1952), Initernicationial Economnic Papers, 2(83).

Directive 2014/104/EU of the European Parliament and of the Council of 26 November 2014 on certain rules governing actions for damages under national law for infringements of the competition law provisions of the Member States and of the European Union (2014), Official Journal of the European Union, L349, 1-19.

Harberger, A. C. (1954), Monopoly and Resource Allocation, American Economic Review, 44(2), 77-87.

Leibenstein, H. (1966), Allocative Efficiency and X-Efficiency, The American Economic Review, 56, 392-415.

Lambertini, L., J. Poyago-Theotoky and A. Tampieri (2017), Cournot competition and "green" innovation: An inverted-U relationship, Energy Economics, 68, 116-123.

Laborde, J.-F. (2017), Cartel damages claims in Europe: How courts have assessed overcharges, Concurrences, 1.

Leibenstein, H. (1966), Allocative Efficiency and X-Efficiency, The American Economic Review, 56, 392-415.

Lerner, A. P. (1934), The Concept of Monopoly and the Measurement of Monopoly Power, Review of Economic Studies, 1(3), 157-175.

Nilsson, C. and J. Dernroth (1995), The strategic grounding of competitive advantage - The case of Scania, International Journal of Production Economics, 41(1-3), 281-296.

Okada, Y. (2005), Competition and productivity in Japanese manufacturing industries, Journal of the Japanese and International Economies, 19(4), 586-616.

Peneder, M. (2012), Competition and Innovation. Revisiting the InvertedU Relationship, Journal of Industry, Competition and Trade, 12(1), 1-5.

Pigou, A. C. (1910), Producers' and Consumers' Surplus, Economic Journal, 20(79), 358-370.

Popper, S., V. Greenfield, K. Crane and R. Malik (2004), Measuring Economic Effects of Technical Barriers to Trade on U.S. Exporters, Planning Report 04-3, RAND Science and Technology.

Renda, A., J. Peysner, A. J. Riley, B. Rodger, R. J. Van Den Bergh, S. Keske, R. Pardolesi, E. L. Camilli and P. Caprile (2006), Making antitrust damages actions more effective in the EU: welfare impact and potential scenarios, Report DG COMP/2006/A3/012.

Schiffbauer M. and S. Ospina (2010), Competition and Firm Productivity, International Monetary Fund Working Papers 10/67, Washington.

Shinjo, K. and N. Doi (1989), Welfare loss calculation for Japanese industries, International Journal of Industrial Organization, 7(2), 243-256.

Stigler, G. (1956), The Statistics of Monopoly and Merger, Journal of Political Economy, 64(1), 33-40. 